\title{
Theories Involved in Recognizing and Implementing International Law in Domestic Contexts
}

\author{
K.A.A.N. Thilakarathna \\ Institute of Human Resource Advancement, University of Colombo, Sri Lanka \\ Tel: +94702768174 E-mail: akalanka@ihra.cmb.ac.lk \\ Nisanka Jayarathna \\ The Open University, Nawala, Sri Lanka \\ Tel: +94712576799 E-mail: nisanka1984@gmail.com
}

\begin{abstract}
The impact of international law on the domestic legal system has never being more visible and potent as we see it today. While this being the case, international law itself does not provide a mechanism as to how international law should be absorbed in to the domestic legal system and that question is left for the country in question to decide. In selecting an appropriate method for introducing international law into the domestic legal system, the theoretical aspirations of monism and dualism has been in the forefront of many books and articles that have been written on the subject, yet it has been rejected as being failing to appraise the actual practises of the countries in question when adopting a particular mechanism for bringing international law into the domestic legal system. This article there for explores the reasons as to why monism and dualism has failed to introduced a methodology in bringing international law into the domestic context and what theoretical explanations could be provided for such failure with a conclusion on a more pragmatic approach in choosing the middle way between monism and dualism.
\end{abstract}

Keywords: Monism, Dualism, International Law, Incorporation, Transformation

DOI: $10.7176 / \mathrm{JLPG} / 109-09$

Publication date:May $31^{\text {st }} 2021$

\subsection{Introduction}

The difference between international law and domestic law did not emerge till the Middle Ages according to Nussbaum (Nussabaun, 1954). Therefore, during those early periods, people were not much bothered with finding ways to incorporate international law into the domestic realm. Back then, the law was thought to be of universal nature without there being any distinction as to what it was meant by domestic law and international law since the norms that created the law emanated from a supreme being. The same author states that, in the twelfth and thirteenth centuries the beginnings of the separation of international and domestic law emerged. The universality of law soon began to crumble and the concept of a sovereign nation with its all-embracing powers to do what it desired in its own territory to the exclusion of others lead to the idea of international law being something different from the domestic law came into prominence.

The idea of a sovereign state gave rise to the idea of one nation with its own set of laws which were absolutely enforced in its own territory. However, this law was limited by the territorial boundaries of a state and it did not apply further than that. Still, the separation between international law and domestic law was not seen since international law which developed with the idea of a nation state was novel at the time. Even at the beginning of the early nineteenth century, international law and domestic law did not collide with one another since the disciplines that were governed by both systems were strangers to one another. International law mainly focused on regulating the conduct of states when they interact with one another and the domestic law was concerned about the internal affairs of the country without having much focus on what happens outside its territory.

During these periods, no conflicts were seen between international law and domestic law. However, this soon changed with the ever growing influenced of international law on the domestic legal system with the emergence of areas such as environmental concerns, human rights issues, and international trade, where there emerged a 
constant conflict between international legal norms and domestic legal norms. This happened somewhere after the end of the second world war. After the second world war, states wanted to strengthen the fabric of international law and they tried to bring international norms into the domestic legal system. Some norms coming under the slogan of 'jus cogens' were accepted as being inviolable at any circumstances. Still the exact method of bringing international law into the domestic sphere was not made clear under international law, and it was left for each sovereign state to decide on the specific approach they would want to adopt.

\subsection{Theoretical Solutions}

There are two main theories that try to explain the relationship between international law and domestic law. These theories are commonly referred to as monism and dualism. Each is in complete contrast to the other and the basis of their respective arguments is also fundamentally different. These two theories in general, are presented in the most abstract form without having much recourse to the actual practice of states. Still any discussion on the relationship between international law and domestic law starts with monism and dualism.

\subsubsection{Monism}

Monism asserts that the validity of both the domestic and international legal orders emanate from a single source (Bjorgvinsson, 2015). The theory implies that, both the domestic legal order and the international legal order are a part of the one and same legal order. Ademola Abbas (A. Abbas, 2015) states that, two systems are like two sides of a coin, where the adjectives of domestic and international only signifies the various aspects of the one and same legal system which does not differentiate between domestic and international law. According to monism, both the international and domestic legal system are horizontal. This means that when it comes to a normative choice, in theory at least, one is not choosing either of the laws as being applicable to a given situation in detriment to the other. What happens is that, since both the systems are parallel to one another, any choice would be legitimate if there is no conflict between the two. In case of a conflict between a domestic legal norm with an international legal norm, the international legal norm will be validated to the detriment of its domestic counterpart.

Kelsen, a prominent figure in the monistic school asserts that since both the domestic and international legal systems are binding as valid law, they must form a unitary law since norms emanating from both the systems are equally valid (Starke, 1936). In his analysis of 'hierarchy of norms', under this unitary normative order, Kelsen finds that for a norm to be valid, it must be validated by a higher norm. When no such validation is possible, such a norm is considered as the ultimate norm and hence called a grundnorm. According to Kelsen, under this unitary system, it is international law which takes the place of the grundnorm. Further, unlike others in the monist school, Kelsen concludes that, in deciding to select either the domestic norm or international norm, both choices would be valid if the logical consequences in selecting either of the norms would remain the same. However, Dr. Kunz and Verdross (Starke, 1936) refuse this ideal of Kelsen and argues that it is not possible to make a decision between the two norms which could have the same logical consequences and that, selecting the international norm is the right thing to do.

While coherence is possible under a monist approach, in case where there is a clear distinction between the international legal norm with a domestic one, monist proclaim that, it should be the international norm that should become applicable. Therefore, under a monistic approach, it is the international law that would take the primary place in this unitary legal system, where the domestic legal system will have to always comply with the international legal norm, or else be made responsible for violating such a norm.

The main difficulty in conceding to the fact that, international law is part of the domestic legal system without having any interventions from any local institutions who would have been able to adopt the particular parts of an international legal norm applicable to such a state while leaving the other parts of that international norm which seems to contradict with the broader notion of state sovereignty. In a practical sense this would be a usurpation of the sovereign powers of a state where international law would take effect against the particular wishes of a country. 


\subsubsection{Monism and Constitutional Theory}

The omnipotence of state sovereignty was blamed for the horrors of the war and the human rights atrocities that were committed during the world war against its own citizenry of a country where the loose notion of state sovereignty meant that, at least with regard to internal affairs of a country, it could do whatever it wanted whenever it wanted to do. As the law-making powers of a state was also linked with the concept of sovereignty, monists were rather sceptical in allowing the domestic institutions to decide on the scope and application of international legal rules and norms under the domestic legal system. Monism asserts that, by placing the supremacy of international law over domestic law, it serves to achieve certain moral principles and justice, specifically, human rights and welfare of the individuals.

Monists also argue that by giving much emphasis on state sovereignty, it undermines the international norms and standards which not only takes primacy under a monistic approach, but which is also required to be undertaken and observed by a country as well. They argue that having separate local standards concerning international legal norms are not acceptable. Under a monistic approach, a constitution would be required to accept the superiority of international law irrespective from whatever source such an international legal norm might have emanated from, whether it was from a treaty law or a principle of customary international law, it would not make any difference to the effect and validity of such an international norm at the domestic legal system.

Under a pure monistic approach, a legislature is always required to respect international law when it enacts new legislations. This would be done without having any regard as to the impact and viability of implementing such a law at the domestic level. The executive and the judiciary would also have to act in good faith regarding the application of international legal norms at the domestic level, even where there is a conflict between the international norm and the domestic norm.

For pragmatic reasons monism in its purest form is difficult to be reconciled with the broader constitutional fundamentals as it is criticized for being democratically deficit. Monism invokes international law to be a part of the domestic law without providing an opportunity for the domestic institutions to either adapt or adopt international legal norms according to the needs of the nation. Monism is incompatible with the democratic lawmaking process since it allows for the making of laws which lacks accountability and predictability as citizens of a country do not have any influence on the lawmaking process of a country where international legal norms automatically dictate the domestic rules.

Regarding separation of powers, any law that becomes valid in a domestic setting go through a certain phrase where the legislature, the executive and the judiciary somehow gets involved or are at least allowed to get involved in the law-making process. At the legislature, the members of the Parliament (or by whatever name a legislature is referred to) gets an opportunity as representatives of the people under a representative democracy to state their claims regarding a particular law, the executive is sometimes allowed to use his veto powers in stopping a law from being passed and the judiciary can be approached to question the validity of a law against its constitutional compatibility. If international law was to become a part of the domestic legal order without any of these procedures or precautions, it would seriously undermine the authority of these institutions since they are accountable and responsible for its citizenry. This severely restricts the sovereignty of a state where it limits the capacity of the national political process to oversee the exact extent of international obligations which a state may prefer to undertake.

From a rule of law perspective, legal certainty is a vital consideration. Adhering to a purely monistic approach may compromise the certainty of a particular law since the same substantive law may yield different results if it were to be interpreted in the context of a domestic norm against an international norm. Under a pure monistic approach, one would have to conclude that, the relevant standard would have to be an international one. However, determining this standard will then again be difficult as most international instruments leaves it to the respective state parties to decide on their own standards according to their capabilities. For example, Article 2 (3) of the International Covenant on Economic, Social and Cultural Rights (ICESCR) provides that developing countries may determine the extent to which they would guarantee the rights mentioned in the covenant to nonnationals. This clearly provides an example for the fact that finding a true international standard to be applied 
across all nations would not be possible. Hence, if international law was to become a part of the domestic legal system without there being any scrutiny along the way by a domestic process, such legal norms would become unworkable at the domestic level. Under a monistic approach in the absence of a universal standard concerning a particular legal norm, it would then become almost impossible to have any legal certainty.

Therefore, it can be concluded that monism under its purest form is incompatible with the broader notions of constitutional fundamentals and therefore, any constitutional mechanism purely based on a monistic approach seems unworkable.

\subsubsection{Dualism}

Dualism is in sharp contrast to monism where it argues that international law and domestic law does not belong in the same unitary system and that both systems are independent from one another unless some kind of connection is made between the two by using domestic law. The main reason for this contention is that, according to dualist, international law and domestic law do not operate in the same sphere. For example, while international law is concerned with the interactions among states themselves, domestic law is primarily concerned with the internal affairs of a state. Therefore, these two systems of law do not belong to the same sphere and hence there cannot be any conflict between the two. Even if there is a conflict, at the domestic level, it would be the domestic law or a norm that would take primacy over an international law or a norm.

Triepel (Bjorgvinsson, 2015) points out three main factors as to why international law should be considered outside the scope of domestic law. Firstly, international law and domestic law comprise of different sources of law. International legal sources are limited when compared to domestic legal sources. International legal sources are primarily laid out in Article 38 (1) of the Statute of the International Court of Justice and when a matter is brought before the ICJ, it cannot look for any outside sources to resolve a conflict. On the other hand, the domestic law of any given country would not strictly prescribe the sources of law in that particular country and would leave the matter open for the courts to decide when and where it becomes necessary to decide whether a particular source of law is acceptable or not at the domestic level. Secondly, the subjects of international law and domestic law are different since international law is primarily concerned with the states and their interactions with one another, whereas domestic law is only concerned with its internal aspects and individuals. Thirdly, the object of both systems is also different. This refers to the substances of law where he claims that since both systems govern different aspects or fields, there cannot be a conflict between the two systems of law.

Unlike monism, dualism gives primacy to domestic law when there is a conflict between a domestic legal norm with an international legal norm. This is in line with the notion of state sovereignty where the omnipotence of the state is reassured through dualism. The theory also asserts that, in giving effect to international law at the domestic level, it must only be done with the sanction of the domestic law itself. This simply means that if a particular legal rule that is found in the domestic legal system allows for the recognition and implementation of international law after following certain procedures such as making an enabling legislation, then only a norm of international law would become a part of the domestic legal system. If not, no matter how attractive or feasible an international legal norm be, it would not become a part of the domestic law. It is also to be pointed out that once a legal norm found in international law becomes a part of the domestic law, it is no longer considered as international law and instead it becomes a part of the domestic law.

Under the theory of dualism, the fact that law must originate from a particular law maker is emphasized. It is argued that unlike in a domestic legal system, the international legal system knows nothing about a lawmaker and therefore, it is by a domestic lawmaker that international law is transformed into the domestic legal order. International law, according to the dualist, purely rests on the consent each state provides for a particular international legal norm. Where some states consent and others do not, the norm only becomes binding upon those who gave consent and not on the others. Further to this, the extent to which a particular state adheres with a given norm of international law is also determined not according to international law but according to domestic law. Most often, a constitution of a country will provide for the status enjoyed by international law in the domestic sphere. 


\subsubsection{Dualism and Constitutional Theory}

Dualism accords with the broader notions of constitutional fundamentals from a theoretical perspective. It reaffirms the sovereignty of states, self-determination, the separation of powers, specially between the legislature and executive in bringing international law to the domestic sphere and the rule of law while ensuring the democratic process in which laws are made.

Dualism tries to make sure that in the domestic sphere, the sovereign states have control over the laws and norms that are applicable under the legal system. The notion of denying automatic incorporation of international law into the domestic sphere is justified on the ground that, to do so would mean that local institutions would have no control over the scope and the ambit of obligations they may have to take at the international level if no domestic scrutiny of international norms were allowed.

Dualism also makes sure that the legislative power of the representatives of the people is also given effect since under a dualist approach, without the intervention of the legislature, it would not be possible to bring in any international legal norms into the domestic sphere. While many countries allow their executives to sign and ratify treaties on behalf of their nations, when it comes to domestic implementation, the intervention of the legislature is made a must. This ensures the separation of powers between the legislature and the executive when it comes to bringing international legal norms into the domestic sphere.

When it comes to the rule of law, dualism is also seen more compatible with the notion of certainty and predictability of laws as an individual would be able to find out whether a particular legal norm is a part of the legal system or not. This can be achieved by looking at the rule of recognition as Hart (Hart, 2012) describes it, where the effect of international law can be determined according to the rule of recognition which allows for the recognition of binding norms from non-binding norms. At any rate, since the standards adopted in evaluating and interpreting laws would have a domestic flavour than an international one, dualism is a pragmatic theory for small developing countries where they can undertake to do what they can, instead of blindly committing to standards which they cannot fulfil. Almost all treaties leave it to the contracting parties to decide upon their own standards when it comes to implementation, apart from those provisions that could not be derogated.

Dualism has its critics as well. When it comes to the role played by legislatures in countries that adopts a monistic approach, their involvement would decide whether they are adhering with the notions of separation of powers and one cannot simply argue that countries adopting a monistic approach would not give any opportunity for the legislature get involved in the recognition and implementation of international law in the domestic sphere. From a rule of law perspective, critics state that, in the realm of human rights, leaving domestic law to set or determine the standards that must be accorded is incompatible with the broader notions human rights which are universal and not domestic. International standards were mainly brought forward due to the inadequacy and the unworkability of the domestic standards and legal certainty, therefore, must give way to legal standards which must be followed to protect the rights of the individuals which are inherent and natural.

The main criticism levelled at dualism is the fact that, while a state may be under an obligation at the international level when they sign and ratify treaties, they are not bound at the domestic level to give effect to them under the domestic system. This is because, dualism does not require any positive assertions regarding the international obligations of a state at the domestic level. A state may sign and ratify many treaties as it may please, like in Sri Lanka, where there are several ratified unincorporated treaties. Dualism only concerns itself with providing the proposition that unless there is a domestic intervention, international legal norms do not automatically become a part of the domestic legal order. However, it fails to provide any guide as to what happens when a state undertakes obligations at an international level without bringing them to the domestic sphere. The only (ir)rational conclusion is that it will not be a part of the domestic law.

\subsection{Conclusion}

Both monism and dualism in their abstract forms have not found any place in state practice. There are no states which are purely monist or which are purely dualist. Fitzmaurice (Fitzmaurice, 1958) opines that the whole monist-dualist argument is unreal, artificial, and irrelevant since it is based upon an assumption that does not 
take place in the real world. This is because international law and domestic law do not have a common sphere in which they could conflict with one another. Chiam (Chiam, 2018) opines that many modern scholars disregard the pure theoretical debate over the opposing explanations provided under monism and dualism concerning the relationship between international law and domestic law since those theories fails to appreciate and capture how international law works within state practice.

Most often, the theory is dependent on the particular source of international law which is being brought in to the domestic sphere. Many countries adopt a dualist approach when it comes to treaties. A treaty becomes a part of the domestic law, when an enabling legislation is enacted and not by mere ratification or accession. After such enabling legislations are enacted, a treaty may become applicable de lege lata or mutatis mundais as the case may be. When it comes to Customary International Law (CIL), most states follow a monistic approach where international legal norms are made a part of the domestic legal system as long as it does not contradict with the existing constitutional provisions and legislative enactments. This is done because it would not be possible to either transform, or incorporate CIL into the domestic legal system through making enabling legislations since CIL emerges in a rather sporadic manner.

\section{Acknowledgement}

The authors would like to acknowledge the support provided by Prof. Wasantha Seneviratne, Professor in Public and International Law, Faculty of Law, University of Colombo, Sri Lanka.

\section{References}

A. Abbas. (2015). The Complete International Law: Cases and Materials . Oxford: OUP.

Bjorgvinsson, D. (2015). The Intersection of International Law and Domestic Law: A Theoretical and Practical Analysis . London: Edward Elgar.

Chiam, M. (2018). Monism and Dualism in International Law-Oxford Bibliographies. Oxford : OUP.

Fitzmaurice, G. (1958). The General Principles of International Law Considered from the Standpoint of the Rule of Law. Leiden: Sijthoff.

Hart, H. (2012). The Concept of Law. Oxford : OUP.

Nussabaun, A. (1954). A Concise History of the Law of Nations. London : McMillan.

Starke, J. G. (1936). Monism and Dualism in the Theory of International Law. Brit YB Int'1 L, 66-81. 